\title{
Localization of Inducible Nitric Oxide Synthase to Mast Cells During Ischemia/Reperfusion Injury of Skeletal Muscle
}

\author{
Aurora Messina, Kenneth R. Knight, Bruce J. Dowsing, Baimeng Zhang, \\ Long H. Phan, John V. Hurley, Wayne A. Morrison, and Alastair G. Stewart \\ Department of Pharmacology (AM, KRK, BJD, BZ, LHP, JVH, WAM), Faculty of Medicine, Dentistry and Health \\ Sciences, University of Melbourne, Parkville; and Bernard O'Brian Institute of Microsurgery (AGS), St. Vincent's \\ Hospital, Melbourne, Victoria, Australia
}

\begin{abstract}
SUMMARY: Nitric oxide contributes to tissue necrosis after ischemia-reperfusion (IR). A biochemical and immunohistochemical study was made of the amounts and localization of both $\mathrm{Ca}^{++}$-independent nitric oxide synthase (NOS) II and $\mathrm{Ca}^{++}$-dependent (NOS I and NOS III) in rat skeletal muscle after ischemia and 0.5, 2, 8, 16, and 24 hours reperfusion. NOS II was not detectable in control muscle or during ischemia, was first detected after 2 hours reperfusion, increased further by 8 hours, and remained elevated at 24 hours. Both NOS II and nitrotyrosine, a marker of peroxynitrite formation, were localized exclusively to mast cells except after 24 hours reperfusion when some macrophages and neutrophils also showed positive immunoreactivity. Mast cells underwent extensive degranulation during reperfusion. NOS I was not detected in injured or control muscle. The level of NOS III, which was localized to the endothelium of blood vessels of all sizes in control muscle, decreased progressively during ischemia and reperfusion to reach undetectable levels after 16 hours reperfusion. These findings indicate that most of the nitric oxide formed during IR injury is generated by NOS II located almost exclusively in mast cells. (Lab Invest 2000, 80:423-431).
\end{abstract}

$L$ ike other forms of inflammation, the reaction that follows reperfusion of ischemic tissue is a complex phenomenon and many factors have been shown to play a role in its pathogenesis (Grace, 1994). One of the mediators implicated in ischemia-reperfusion (IR) injury is nitric oxide (NO) (Knight et al, 1997; Knox et al, 1994; Noiri et al, 1996; Phan et al, 1994; Seekamp et al, 1993; Zhang et al, 1997), which may act either alone, or in combination with superoxide anion, as the potent oxidant peroxynitrite (Beckman et al, 1990; Forstermann and Kleinert, 1995; Pryor and Squadrito, 1995). NO is synthesized from L-arginine by three widely distributed, functionally distinct, and closely regulated nitric oxide synthases (NOS), NOS I, II, and III. NOS I and NOS III are $\mathrm{Ca}^{++}$-dependent constitutive enzymes (cNOS), whereas NOS II is a $\mathrm{Ca}^{++}$. independent inducible enzyme (Moncada et al, 1991). NO may be cytotoxic or cytoprotective (Moncada et al 1991), depending on the location and level of production.

The role of NO in IR injury has been explored in a variety of tissues with conflicting results (Stewart et al, 1999). In heart and gut, NO has been reported to have

Received December 17, 1999.

This work was supported by National Health and Medical Research Council (Australia), and Transport Accident Commission (Victoria, Australia).

Address reprint requests to: Dr. A. Messina, Bernard O'Brien Institute of Microsurgery, St Vincent's Hospital, 42 Fitzroy St., Fitzroy, Melbourne, Victoria, Australia 3065. Fax: 6139416 0926; messinaa@svhm.org.au a protective role. By contrast, deleterious effects have been reported in skeletal muscle, skin, and brain. These discrepant observations may be caused by the differential importance, in different tissues, of the beneficial effect of vasodilatation and inhibition of leukocyte activation by cNOS-derived $\mathrm{NO}$ and the damage caused by NOS II-derived NO and its products (Stewart et al, 1999).

In previous studies, we and others have demonstrated that NOS was active during reperfusion of ischemic skeletal muscle and that administration of a range of NOS inhibitors significantly increased muscle survival (Knight et al, 1997; Noiri et al, 1996; Phan et al, 1994). Although these results indicated that NO was deleterious, they did not elucidate the relative contribution of each of the NOS isoforms, nor was it possible to determine the temporal sequence of changes in NOS activity or expression. Furthermore, these studies did not identify the cellular source of NOS.

The present report describes an immunohistochemical and biochemical study of the anatomical distribution and activity of the NOS isoforms during the development of IR injury in skeletal muscle. The localization of nitrotyrosine, a marker of the oxidation product of $\mathrm{NO}$, peroxynitrite, is also described.

\section{Results}

\section{NOS Activity in Normal and IR Muscles}

A temporal study of the levels of inducible NOS (NOS II, $\mathrm{Ca}^{++}$independent) and constitutive NOS (both 
NOS I and NOS III, $\mathrm{Ca}^{++}$dependent) activity was undertaken (Fig. 1). NOS II activity was undetectable in control muscle or immediately after ischemia, was first detected after 2 hours reperfusion, increased further after 8 hours reperfusion, and remained elevated after 24 hours reperfusion. Constitutive NOS activity (4.39 $\pm 1.04 \mathrm{pmol} / \mathrm{mg} / \mathrm{minute}$ ) was detectable in muscles before any treatment. Its level decreased progressively during ischemia and reperfusion to reach very low levels by 16 hours reperfusion and was undetectable after 24 hours reperfusion. Qualitative RT-PCR showed NOS II mRNA expression immediately after ischemia and at 8,16 and 24 hours after reperfusion (Fig. 2, lanes 2, 6, 8, and 10) but not in control muscle extracts (Fig. 2, lanes 1, 3, 5, 7, and 9) or after 2 hours reperfusion (Fig. 2, lane 4).

\section{Localization of NOS Isoforms and Nitrotyrosine in Normal and IR Muscle}

The cellular source of the NOS isoforms and nitrotyrosine after IR was identified using both indirect and avidin-biotin complex method (ABC) methods of labeling. The $A B C$ method occasionally (2 of 10) gave false positives for mast cell labeling in this setting. In each case, some of the mast cells in sections, on which the primary antibody was omitted, were labeled. The primary antibody was excluded on a representative section from each time point in every staining run ( $A B C$ and indirect). The false positive runs were excluded from the study. Labeling by NOS II and nitrotyrosine antibodies was similar at all times examined and will be described together. Neither NOS II nor nitrotyrosine was detectable in control muscle. Immediately after ischemia, strong positive labeling was detected in large rounded or oval-shaped cells that were closely associated with blood vessels located in the perimysium and epimysium (Figs. 3, a to c, and 4). Double staining with NOS II antibody and toluidine blue (TB) (Fig. 3d) and comparison with adjacent sections stained with TB identified the NOS II positive

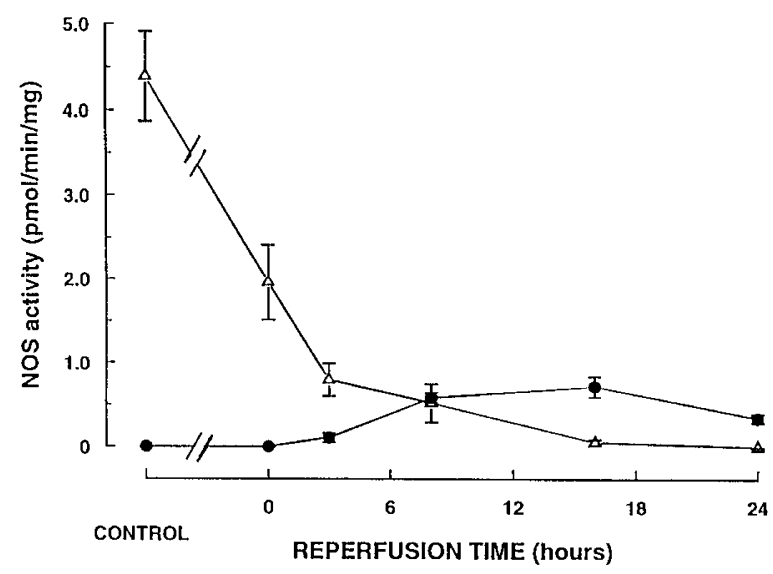

Figure 1.

Nitric oxide synthase (NOS) activities of control and ischemia-reperfusion (IR) rat skeletal muscle. Level of calcium-dependent NOS activity $(\Delta)$ and calciumindependent NOS activity $(\bullet)$ in control and IR rat skeletal muscle. Results are means $\pm \operatorname{SEM}(n=7)$.

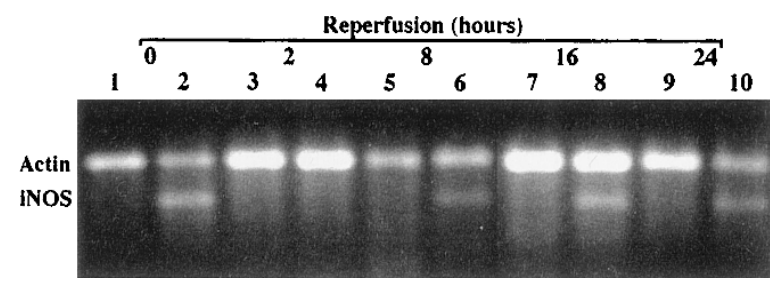

Figure 2.

NOS II mRNA expression in control and IR skeletal muscle. NOS II mRNA is expressed immediately after ischemia and at 8,16, and 24 hours after reperfusion (lanes 2, 6, 8, and 10) but not in control muscle extracts (lanes 1 , $3,5,7$, and 9) or after 2 hours reperfusion (lane 4). Amplified $\beta$-actin was expressed in all samples, confirming the integrity of the RNA extracts.

cells as mast cells. Mast cells were not labeled, at any stage of reperfusion, when antibodies of irrelevant specificity but of the same isotype, were substituted for anti-NOS II (Fig. 3e) or anti-nitrotyrosine. At all stages of reperfusion examined, positive labeling of mast cells persisted but their appearance varied as described in detail below. Up to 16 hours reperfusion, no cells other than mast cells were labeled with NOS II antibody but after 24 hours reperfusion, some of the neutrophils and macrophages now present in the extravascular tissue showed strong positive labeling (data not shown).

\section{Histologic Appearance of Mast Cells During IR Injury}

In control muscle, mast cells are 10 to $15 \mu \mathrm{m}$ diameter oval cells whose cytoplasm is packed with granules staining metachromatically with TB but negatively with NOS II antibody. During IR, mast cells exhibit an increasing degree of degranulation. Quantification of these morphologic appearances are provided (Fig. 5). Immediately after ischemia, a minority of mast cells are small and fully granulated (Figs. $3 a$ and $4 a$ ) but approximately $80 \%$ of mast cells are large and partially degranulated (Figs. $3 \mathrm{~b}$ and $4 \mathrm{~b}$ ). The granules both within mast cells and in the extracellular tissue are positively labeled with both TB and NOS II antibody. The degree of degranulation increases during reperfusion and by 8 hours reperfusion, $76 \%$ of mast cells show extensive degranulation and have a "doughnut" appearance, consisting of a central unlabeled region and a thin peripheral circle of labeled granules (Figs. 3c and 4c). By 24 hours reperfusion, this type of degranulated mast cells is no longer detected and mast cells appear similar to those seen in control muscle. For each of the cell appearances, there is an effect of time that is significant $(p<0.01)$. In the case of the small cells, the proportion differs from that in controls at $0,8,16$, and 24 hours. The proportion of large cells differs from controls at 0 hours. The proportion of doughnut cells differs from that in controls at 8 and 16 hours.

The number of mast cells per unit area of muscle parenchyma (mast cell density) is shown in Figure 6. The numerical density of toluidine blue positive mast cells remained relatively constant during ischemia, increased rapidly during the first 30 minutes of reperfusion, and 


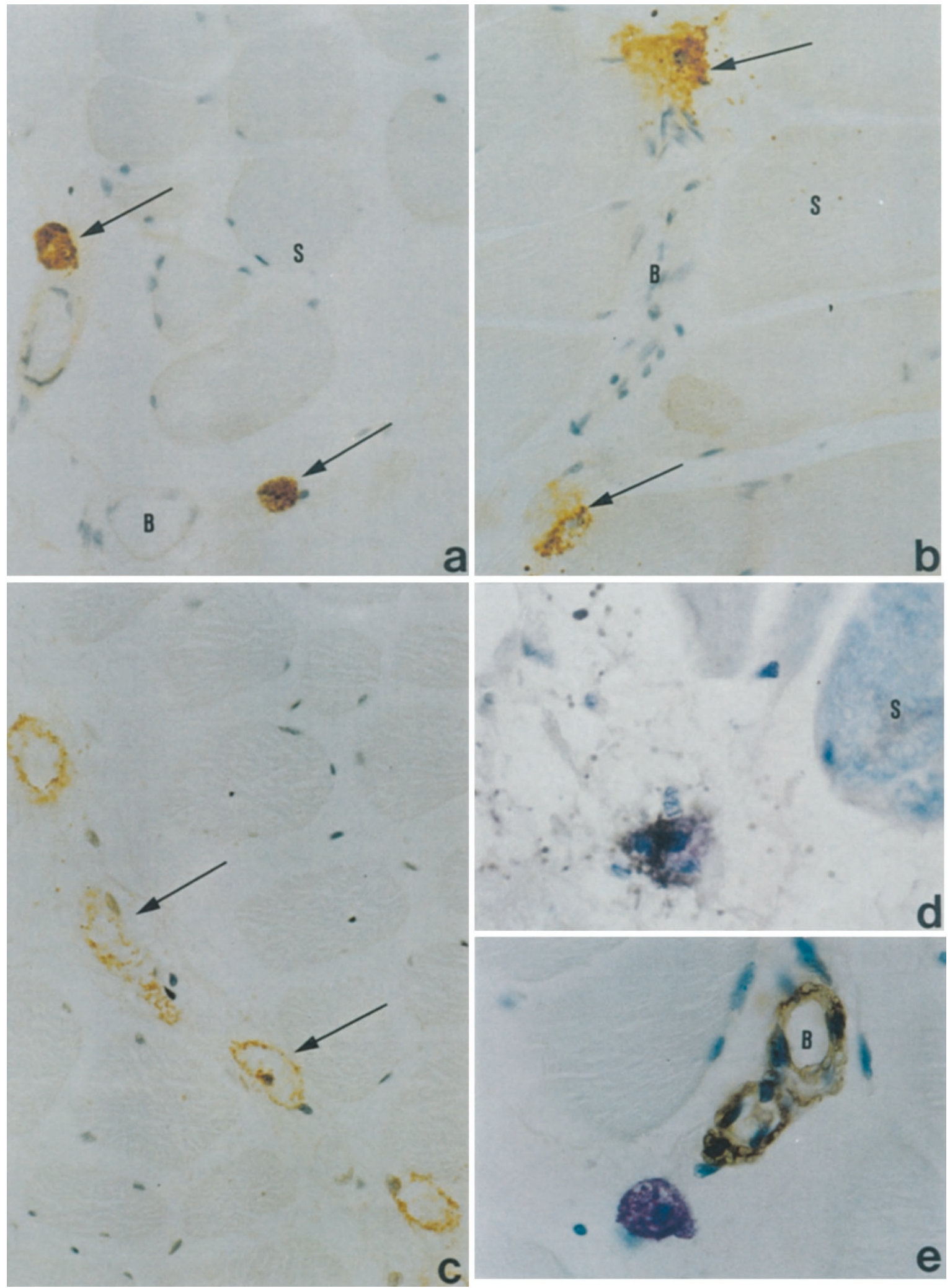

\section{Figure 3.}

NOS II immunoreactivity of mast cells in rat skeletal muscle after IR. Immunohistochemical labeling of NOS II (isotype IgG2a) in intact mast cells (a) and partially degranulated mast cells (b) immediately after ischemia, magnification, $\times 700$, and in extensively degranulated mast cells after 8 hours reperfusion (c), magnification $\times 700$. Note the contrasting appearance of intact (a), partially degranulated (b), and extensively degranulated (c) mast cells. Mast cell, immediately after ischemia, showing co-localization of NOS II positive immunoreactivity with toluidine blue (TB) metachromasia (d), magnification, $\times 700$. The diamino-benzidine chromagen (brown) is converted to black after TB counterstaining. Mast cell and a blood vessel at 30 minutes post-reperfusion showing $\alpha$-actin (isotype IgG2a) labeling of the blood vessel wall $(B)$ and TB metachromasia of the mast cell $(e)$, magnification, $\times 700$. Note: there is no co-localization of anti- $\alpha$-actin and TB metachromasia. (a to c); hematoxylin counter-stain. (B) blood vessel, $(S)$ skeletal muscle fiber. 


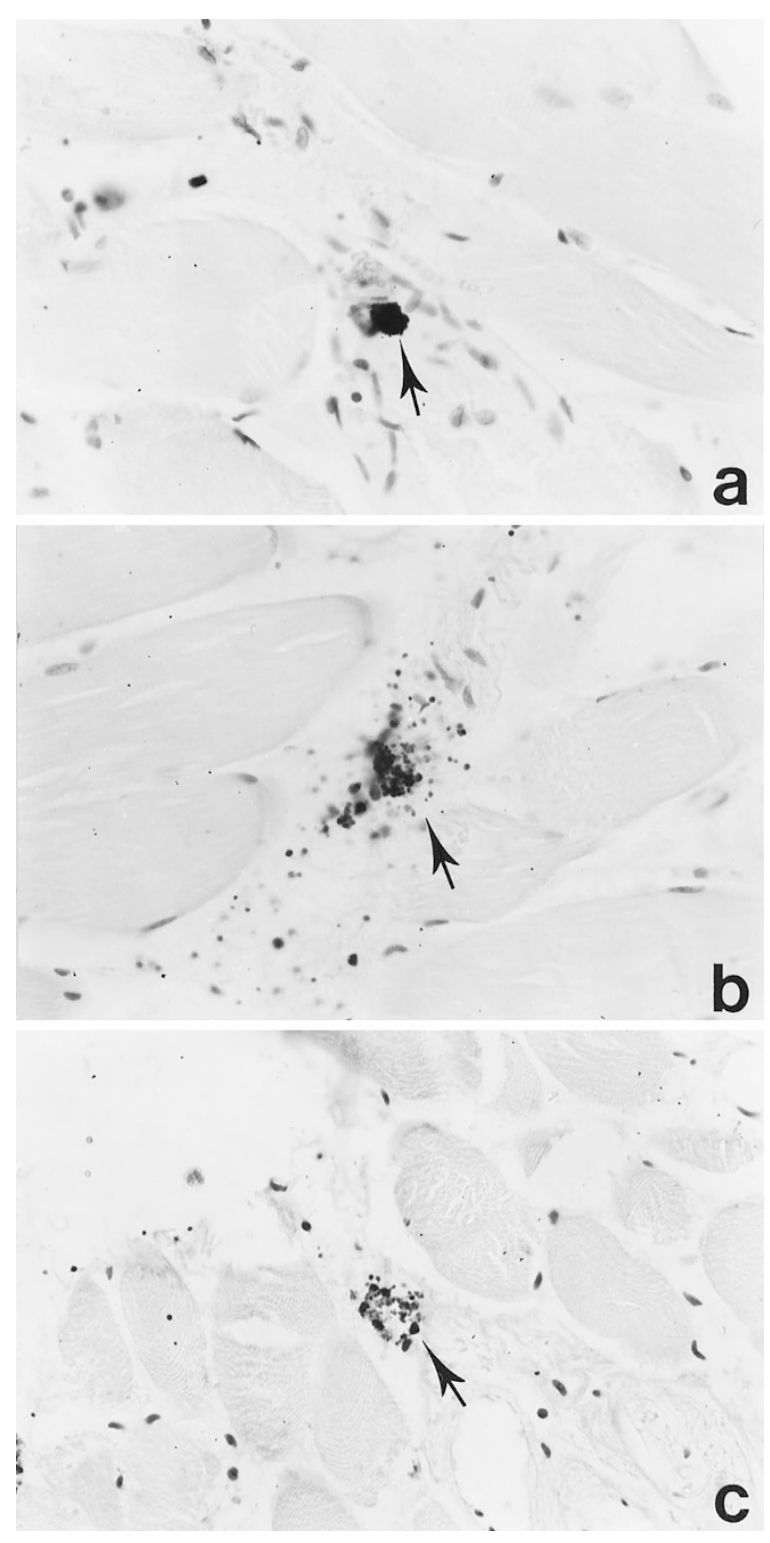

Figure 4.

Nitrotyrosine immunoreactivity of mast cells in rat skeletal muscle after IR. Immunohistochemical labeling of nitrotyrosine in mast cells immediately after ischemia (a and b) and after 8 hours reperfusion (c). Magnification, $\times 350$; hematoxylin counterstain.

then decreased progressively over the next 24 hours. Approximately half the mast cells were NOS II positive immediately after ischemia and at 30 minutes postreperfusion. There was no difference in TB and NOS II mast cell densities from 8 to 24 hours reperfusion. The density of cells detected by anti-NOS II increased significantly from 1.4 mast cells $/ \mathrm{mm}^{2}$ immediately after ischemia to $4.4(p<0.01)$ mast cells $/ \mathrm{mm}^{2}$ during the first 8 hours of reperfusion, then decreased progressively from 4.4 to 1.2 mast cells $/ \mathrm{mm}^{2}(p<0.01)$ by 24 hours.

\section{NOS I}

NOS I was not detected in either control or IR muscle, but it was detected in brain tissue used as a positive control.

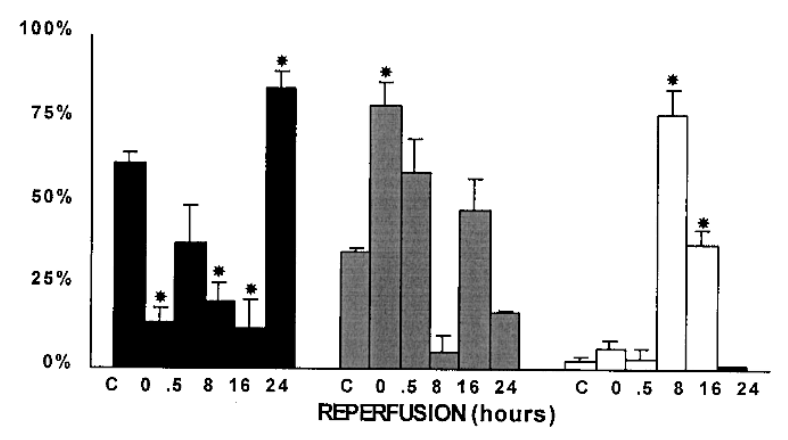

Figure 5 .

Mast cell morphologic appearance during reperfusion. Mast cells are divided into three categories based on the extent of their degranulation, in control muscle $(C)$, and during a 24-hour reperfusion period. i, intact $\mathbf{\square}$; partially degranulated $\square$; and extensively degranulated $\square$. Results are mean percentage of total mast cells $(n=3){ }^{*} p<0.01$ treated vs respective control.

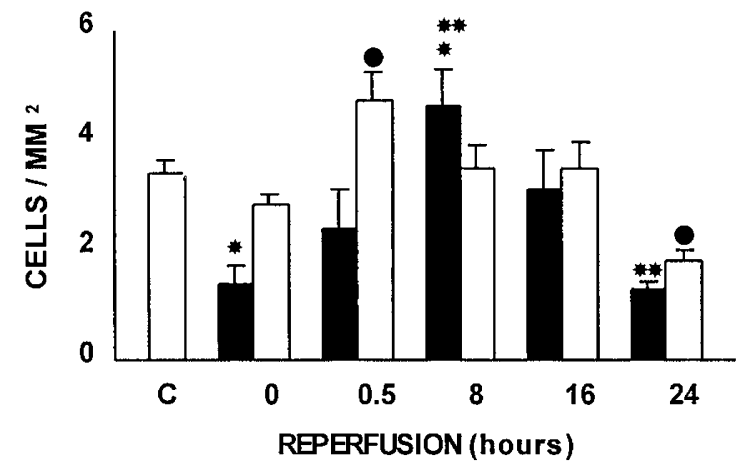

Figure 6.

Numerical density of TB-stained mast cells and NOS II-positive cells. Numerical densities (cell/ $/ \mathrm{mm}^{2}$ tissue) of mast cells staining with TB or NOS II in control muscle $(C)$ and at different stages of reperfusion (TB $\square$ ) (NOS II $\mathbf{\square}$ ). Results are means \pm SEM $(n=3), p<0.01$, NOS II (\#, 0 hours v/s 8 hours) and (**, 8 vs 24 hours), TB (๑, 0.5 vs 24 hours).

\section{NOS III}

There was moderate labeling of vascular endothelium of vessels of all types in control muscle (not shown). Labeling of larger vessels was unaltered by ischemia and reperfusion. The intensity of capillary labeling increased after ischemia (Fig. 7a) but decreased progressively and in a patchy manner during reperfusion, so that areas of intensely labeled capillaries lay adjacent to areas that were unlabeled by anti-NOS III (not shown). No capillaries were labeled after 16 hours reperfusion (Fig. 7b), but by 24 hours reperfusion, areas of intensely labeled capillaries are again present, adjacent to unlabeled areas (Fig. 7, $c$ to d).

\section{Discussion}

The findings of the present study, together with our previous observations of protective effects of NOS inhibitors in IR injury to skeletal muscle (Knight et al, 1998; Phan et al, 1994; Zhang et al, 1997), implicate mast cell NOS II induction in the pathogenesis of IR injury. NOS II activity increased during reperfusion and both NOS II and nitrotyrosine were localized exclusively to mast cells after ischemia and up to 16 hours 


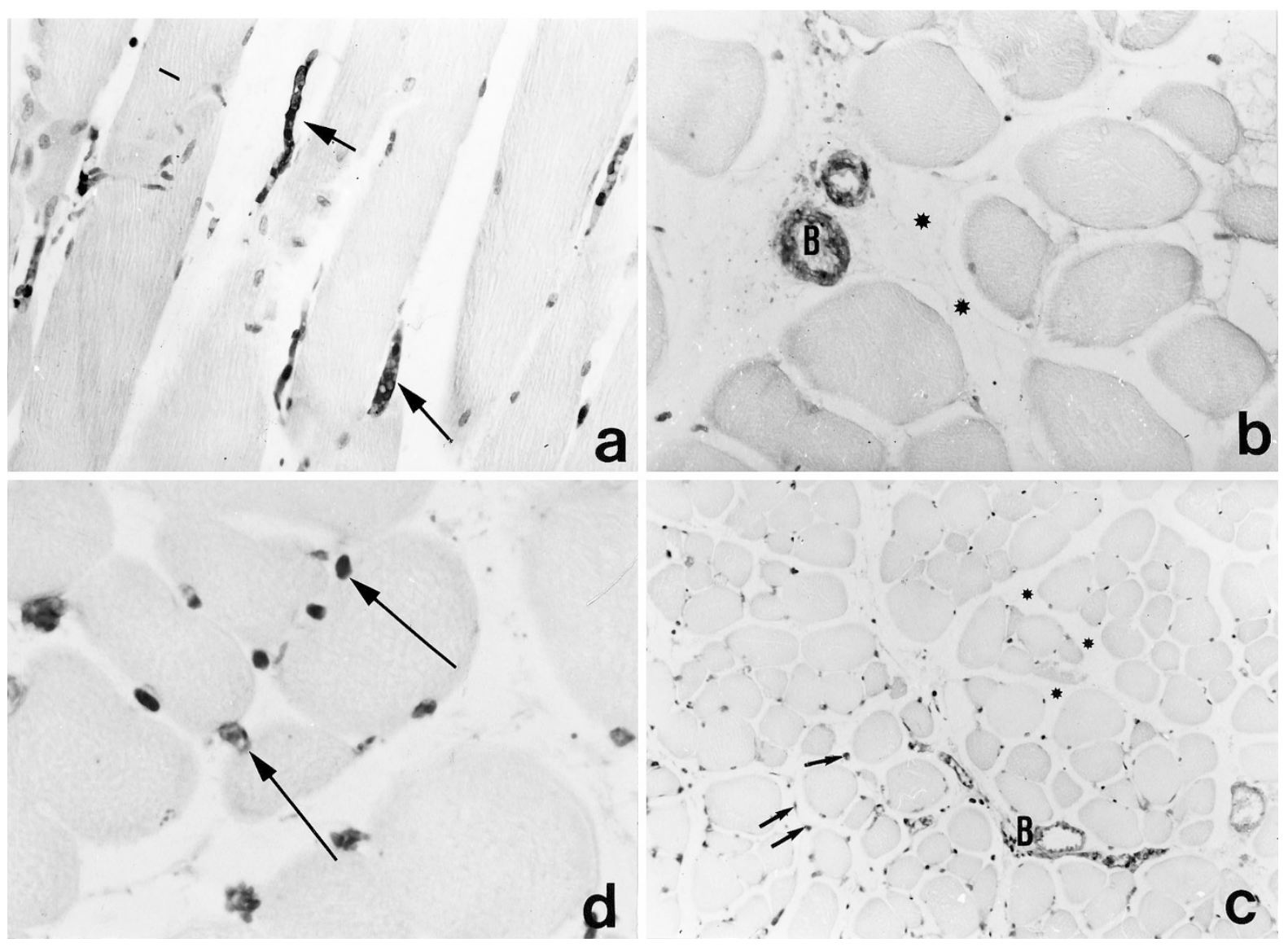

\section{Figure 7.}

NOS III immunoreactivity of capillaries in rat skeletal muscle after IR. Immunohistochemical labeling for NOS III in capillaries (arrows) immediately after ischemia (a), magnification, $\times 430$; after 16 hours reperfusion (b), magnification, $\times 430$; after 24 hours reperfusion (c), magnification, $\times 220$, and (d), magnification, $\times 600$. Labeled capillaries (arrows), unlabeled capillaries $\left(^{*}\right)$, blood vessels $(B)$.

reperfusion. Many neutrophils and some monocytes/ macrophages were present in the muscle parenchyma from 8 hours reperfusion onwards, but we did not detect NOS II protein or nitrotyrosine in these cells until 24 hours reperfusion. Our observations indicate that ischemia up-regulates NOS II in resident mast cells and causes partial degranulation. Mast cells are resident tissue cells derived from bone marrow precursors that were first identified by Ehrlich on the basis of their numerous metachromatically staining cytoplasmic granules (Galli, 1990). They are a heterogeneous population of cells, the phenotype of which can be regulated by their micro-environment (Galli, 1990; Galli, 1997; Lutzelschwab et al, 1997; Metcalfe et al, 1997). During reperfusion mast cells undergo a process of activation, reflected in the apparent increased cell size and the intensity of NOS II labeling, followed by extensive degranulation that results in a striking "doughnut" appearance of these cells after 8 hours. This sequence of events is reminiscent of anaphylactic degranulation, characteristic of mast cell activation in allergic responses. At 8 hours reperfusion, the numerical density of NOS II positive cells was slightly higher than that for TB-labeled cells, although this was not statistically significant. These NOS II-positive, TBnegative cells were identified on the basis of morpho- logic appearance alone and may represent extensively degranulated mast cells, however other possibilities cannot be ruled out.

The decrease in the $\mathrm{Ca}^{++}$-dependent NOS activity muscle is likely to be caused by loss of NOS III, rather than NOS I, as NOS III but not NOS I was readily detectable in skeletal muscle. Furthermore, after the ischemia-associated transient increase in NOS III immunoreactivity, the levels progressively declined during reperfusion with a similar time-course to that of the change in the $\mathrm{Ca}^{++}$-dependent NOS activity. During the early stages of reperfusion, NO release is markedly decreased (Ma et al, 1993; Sobey et al, 1992; Sternbergh et al, 1993). In our study, the apparent discrepancy between the increase in NOS III immunoreactivity observed at the end of ischemia and the diminished activity of $\mathrm{Ca}^{++}$-dependent NOS in muscle homogenates may result from ischemia-induced oxidative inactivation of the transiently increased amounts of constitutive NOS protein. The increase in NOS III immunoreactivity during ischemia is consistent with recent studies showing that both acute and chronic hypoxia are stimuli for NOS III expression (Gess et al, 1997; Lecras et al, 1996). As reperfusion progressed a large proportion of vasculature became NOS III negative. However, immunolabeling for NOS III protein 
remained intense in the vasculature of patches of muscle until 8 hours reperfusion. Loss of NOS III activity, caused by either loss or inactivation of NOS III protein, would be expected to result in vasoconstriction, neutrophil extravasation, and edema, which could contribute to cell death by extending the episode of ischemia through the "no-reflow" phenomenon (Ames et al, 1968; Kanwar and Kubes, 1995; Kubes, 1993; Menger et al 1997). Pharmacological treatments that increase $\mathrm{NO}$ levels early during reperfusion or ischemic pre-conditioning (which is in part NOS III-mediated), protect skeletal muscle from IRmediated constriction and edema (Akimitsu et al, 1995; Chen et al, 1998; Huk et al, 1997; Pudupakkam et al, 1998). However, there is a dissociation between early vascular reperfusion and neutrophil infiltration from parenchymal injury and death in skeletal muscle IR (Breidahl et al, 1996; Hickey et al, 1996; Skjeldal et al, 1993, 1994). Extensive mast cell degranulation may be important in the initiation of IR injury, whereas neutrophil involvement may be secondary to the damage (Breidahl et al, 1996; Petrasek et al,1994; Skjeldal et al, 1993). NOS II was not detected in neutrophils until 24 hours reperfusion, at which time IR injury had induced extensive necrosis.

The NOS inhibitor L-NAME and the NOS II gene repressor dexamethasone improved muscle survival when administered 3 hours post-reperfusion at a time when the level of $\mathrm{Ca}^{++}$-dependent NOS activity had declined to less than $10 \%$ of the control level. Thus, any protective effects of L-NAME could be ascribed to inhibition of NOS II, which does not appear to cause irreversible injury until at least 3 hours after reperfusion. The cytotoxic effects of NO are largely a result of its combination with superoxide anion to form peroxynitrite. The latter adduct gives rise to the highly toxic hydroxyl radical that indiscriminately binds to and inactivates macromolecules. Nitrotyrosine can be used as a footprint for peroxynitrite. However, nitrotyrosine residues can also be generated by reaction of NO with hypochlorous acid or myeloperoxidase (Eiserich et al, 1998; Sampson et al, 1998). Nevertheless, detection of protein nitrotyrosine in conjunction with NOS II in the mast cells is not inconsistent with peroxynitrite formation. Nitrotyrosine immunoreactivity was restricted to mast cell granules and peroxynitrite has a short half-life (Beckman et al, 1990), decreasing the likelihood that peroxynitrite has effects beyond mast cell granules. Although NO inhibits mast cell degranulation, low concentrations of peroxynitrite promote degranulation of mast cells (Barker and Stewart, 1998) and may contribute to this process in IR. Peroxynitrite-facilitated mast cell degranulation could mediate IR injury through the actions of many factors, including arachidonic acid derivatives, TNF- $\alpha$, and IL-1, all of which have been implicated in the pathogenesis of IR injury to skeletal muscle (Grace, 1994; Seekamp et al, 1993). Resident mast cells mediate a significant component of IR injury in cardiac muscle in the absence of migrating leukocytes (Keller et al, 1988). Pharmacological interventions that stabilize mast cells during IR, have been shown to be protective in heart, lung, and gut (Barr et al, 1998; Jolly et al, 1982; Keller et al, 1988).

Two independent actions of NOS may contribute to the pathology of skeletal muscle IR. A decrease in constitutive NOS activity caused by deficiency of NOS III in the early stages of reperfusion contributes to microvascular dysfunction, neutrophil infiltration, but not muscle cell death. In the later stages of reperfusion, the NOS II activity resulting from induction of NOS II in mast cells contributes to muscle cell death via amplification of the inflammatory processes.

We have shown for the first time that NOS II and nitrotyrosine are localized exclusively to the mast cells in rat gastrocnemius muscle after ischemia and up to 16 hours reperfusion, and that during the first 8 hours of reperfusion, mast cells undergo extensive degranulation. The exclusive localization of NOS II to mast cells during the development of IR injury and the protective effects of NOS II-selective inhibitors (Zhang et al, 1997) implicate mast cell-derived NO or its derivatives in the pathogenesis of IR injury to skeletal muscle.

\section{Materials and Methods}

\section{IR ModeI}

All procedures were carried out with the approval of the St Vincent's Hospital Animal Ethics Committee and conformed to National Health and Medical Research Council guidelines on animal experimentation. Male Sprague-Dawley rats (weight 200 to $350 \mathrm{~g}$ ) were anesthetized with intraperitoneal pentobarbitone (60 $\mathrm{mg} / \mathrm{kg}$ body weight). Warm ischemia $\left(36 \pm 1^{\circ} \mathrm{C}\right.$ ) of the right hind limb was produced using a tourniquet, consisting of a tightly wound elastic band, that was placed on the limb proximal to the gastrocnemius muscles. This technique produces complete ischemia and after 2 hours application only $15 \%$ to $20 \%$ of the gastrocnemius muscle survives after 24 hours of reperfusion, as assessed by the nitroblue tetrazolium reaction (Knight et al, 1997). Rats were allowed to recover and after the appropriate period of time were re-anesthetized with intraperitoneal pentobarbital (60 $\mathrm{mg} / \mathrm{kg}$ ). Tissue was collected after ischemia without reperfusion and after various periods of reperfusion.

\section{Experimental Protocol}

NOS Activity. Gastrocnemius muscles were harvested from sham-operated rats and after a period of 2 hours warm ischemia and 2, 8, 16, and 24 hours reperfusion ( $n=7$ each group). Cross-sections were cut, snap frozen in liquid nitrogen, freeze-dried, and stored at $-70^{\circ} \mathrm{C}$ until assayed for NOS activity (7). NOS activity was measured biochemically as the conversion of $\left[{ }^{3} \mathrm{H}\right]$ L-arginine to $\left[{ }^{3} \mathrm{H}\right] \mathrm{L}$-citrulline by the cell-free homogenate (Zhang et al, 1997). Briefly, the tissue samples were homogenized on ice in an ultraTurrax T 25 homogenizer in buffer. The homogenate was then centrifuged at $1000 \mathrm{~g}$ (Sorvall RT6000D) for 15 minutes at $4^{\circ} \mathrm{C}$ and the supernatant carefully removed and stored briefly ( $<1$ hour) on ice. The 
reaction was started by adding $100 \mu$ l of supernatant (containing approximately $500 \mathrm{mg}$ protein) to $200 \mu \mathrm{l}$ of reaction buffer $(\mathrm{pH} 7.5)$ containing $\left[{ }^{3} \mathrm{H}\right]$ L-arginine. Samples were incubated for 60 minutes at $37^{\circ} \mathrm{C}$ and then the reaction was stopped by addition of $1.5 \mathrm{ml}$ of Hepes buffer adjusted to $\mathrm{pH} 7.5$. The admixture was applied to $1 \mathrm{ml}$ of Dowex 50W ( $\mathrm{Na}^{+}$form) column that was eluted with $1.5 \mathrm{ml}$ of distilled water. The amount of ${ }^{3} \mathrm{H}$ in the sample effluent and $1.5 \mathrm{ml}$ water wash containing the $\left[{ }^{3} \mathrm{H}\right]$ L-citrulline was measured on an LKB scintillation spectrometer. The total NOS activity was determined by measuring the difference in the amount of $\left[{ }^{3} \mathrm{H}\right] \mathrm{L}$-citrulline produced between homogenates incubated in the presence and absence of 300 $\mathrm{mm}$ nitro-imino-L-ornithine (L-NIO), a concentration that completely inhibits NOS activity under these cell-free conditions. The $\mathrm{Ca}^{++}$-dependent NOS activity was determined as the difference between the total NOS activity and the activity in samples incubated in a reaction mixture containing $2 \mathrm{~mm}$ EGTA and no $\mathrm{CaCl}_{2}$. The $\mathrm{Ca}^{++}$-independent enzyme activity was calculated as the difference between the total and the $\mathrm{Ca}^{++}$-dependent NOS activity. All activities are expressed as $\mathrm{pmol} / \mathrm{minute} / \mathrm{mg}$ protein. Protein concentration was measured spectrophotometrically using the Biorad reagent with bovine serum albumin (BSA) as the standard.

Expression of NOS II mRNA in Skeletal Muscle. The NOS II oligonucleotide primers used were based on published rat liver NOS II nucleotide sequences and have been described previously (Adachi et al, 1993). Both gastrocnemius muscles were harvested from sham-operated rats and after a period of 2 hours warm ischemia and 2, 8, 16, and 24 hours reperfusion in IR rats ( $n=3$ each group). Cross-sections were cut and snap frozen in liquid nitrogen, freeze-dried, and stored at $-70^{\circ} \mathrm{C}$ before RNA extraction. Total RNA was isolated by guanidinium isothiocyanate and phenol-chloroform extraction (Chomczynski and Sacchi, 1987). Each RT-PCR reaction was repeated several times. Total RNA $(0.5 \mu \mathrm{g})$ from rat gastrocnemius muscle, LPS-treated lung, and normal lung were used as templates for cDNA synthesis, using Moloney murine leukemia virus (M-MLV) reverse transcriptase and specific NOS II and $\beta$-actin primers as described in a Gene Amp RT-PCR kit (Perkin Elmer Cetus, Norwalk, Connecticut). Samples incubated without RT or without RNA in the cDNA synthesis reaction served as controls for DNA contamination. Inducible NOS and $\beta$-actin RNA were amplified by PCR according to the manufacturer's instructions with $0.5 \mu \mathrm{g}$ of each NOS II primer and $0.4 \mu \mathrm{g}$ each $\beta$-actin primer. LPS-treated and normal lung acted as positive and negative controls for NOS II expression, respectively. Amplification was performed on a Perkin Elmer 2400 PCR Machine (Perkin Elmer Cetus) in the following buffer: $10 \mathrm{~mm}$ TrisHCl (pH 8.3), 2 mM MgCl, 50 mM KCl, $200 \mu$ leach dNTP, $0.01 \%(w / v)$ gelatin, and 2.5 units of Taq Polymerase (Perkin Elmer Cetus). The reaction mixture was heated to $94^{\circ} \mathrm{C}$ for 3.5 minutes, and 40 cycles of denaturation $\left(94^{\circ} \mathrm{C}, 30\right.$ seconds), annealing $\left(55^{\circ} \mathrm{C}, 40\right.$ seconds), and extension ( $72^{\circ} \mathrm{C} ; 35$ seconds for NOS
II, 60 seconds for $\beta$-actin) were carried out. One-tenth of the total PCR mix was resolved by $1.8 \%$ agarose/ TAE slab gel electrophoresis and PCR products were visualized by ethidium-bromide staining. NOS II and $\beta$-Actin PCR reactions were loaded into the same lane for comparison.

Immunohistochemistry for NOS Isoforms and Nitrotyrosine. Gastrocnemius muscles were harvested from sham-operated rats, immediately after ischemia and after $0.5,8,16$, and 24 hours reperfusion $(n=3$ each group). Cross-sections from each muscle were immersion fixed with $4 \%$ paraformaldehyde in $0.01 \mathrm{M}$ phosphate buffered saline (PBS), $\mathrm{pH} 7.4$, for 3 hours, washed in PBS, processed, and embedded in paraffin. Blocks were sectioned at $5 \mu \mathrm{m}$ and mounted onto poly-l-lysine-coated glass slides.

The localization of NOS isoform proteins and nitrotyrosine was determined by immunohistochemistry. NOS II and NOS III were monoclonal isotypes IgG2a and IgG1, respectively, and anti-NOS I was polyclonal. All were purchased from Transduction Laboratories, (Lexington, Kentucky) and used at $10 \mu \mathrm{g} / \mathrm{ml}$ (NOS I and III) and $1 \mu \mathrm{g} / \mathrm{ml}$ (NOS II) in PBS. Monoclonal antibody to nitrotyrosine (Upstate Biotechnology, Lake Placid, New York), was used at $8 \mu \mathrm{g} / \mathrm{ml}$. Additional antibodies of irrelevant specificity, IgG2a anti$\alpha$-actin (Dako Corporation, Carpinteria, California), IgG1 anti-S-100 (Sigma, St. Louis, Missouri ), polyclonal anti-neurofilament 200 (Sigma), and nonimmune mouse and rabbit IgG (Dako) were used at 10 $\mu \mathrm{g} / \mathrm{ml}$. In additional control sections, the primary antibody was omitted. All immunohistochemistry was carried out at room temperature. Sections were rehydrated, permeabilized in $0.1 \%$ Triton- $\times 100$ in PBS for 10 minutes, pre-incubated with normal rabbit or sheep serum $(1: 20)$ for 20 minutes, then incubated with primary antibody overnight. After washing with PBS, sections were incubated in 3\% hydrogen peroxide to block endogenous peroxidase activity, and washed again in PBS. At this stage two protocols were followed. One group of sections were labeled using an ABC method. They were incubated with a biotinylated rabbit anti-mouse or sheep anti-rabbit secondary antibody (Dako) for 1 hour (dilution 1:100) at room temperature, washed in PBS, then incubated in horseradish peroxidase-conjugated streptavidin for $30 \mathrm{~min}-$ utes. A second group of sections were labeled using an indirect antibody method. This group was incubated with horseradish peroxidase-conjugated sheep anti-rabbit immunoglobulin (Silenus, Hawthorn, Victoria, Australia) or rabbit anti-mouse immunoglobulin (Dako) for 30 minutes (dilution 1:100). Peroxidase activity was visualized by incubating sections in PBS containing $0.01 \%$ hydrogen peroxide and $0.025 \%$ diaminobenzidine for 3 to 5 minutes and counter stained with $0.1 \%$ toluidine blue or hematoxylin. Representative sections from each time point underwent immunohistochemical processing at the same time.

Mast Cell Morphology. Sections were viewed at $\times 200$ magnification using an Olympus $\mathrm{BH}-2$ microscope. For each time point 60 to 200 NOS II positive cells were counted in 3 to 9 sections and categorized 
according to their morphologic appearance. The identity of sections analyzed was generally known to the observer because of the distinctive morphologic appearance of the muscle at the various stages of reperfusion. However, the data was collected in total before the final calculation for mast cell numbers and their appearance were carried out. The morphologic appearances were divided into three categories, namely intact, partially degranulated, and degranulated according to the following criteria. Intact mast cells had a round to oval shape, had a clearly defined cell membrane, and were associated with none or fewer than 10 granules in the immediate extracellular space. Partially degranulated mast cells had an oval or irregular shape and their cell membrane was obscured by numerous granules both in the cytoplasm and in the extracellular space. Extensively degranulated mast cells had a thin rim of granules around the cell membrane, but no granules in the remaining more-central cell cytoplasm.

Cell Counts. For each time point, the number of NOS II-positive or TB-stained mast cells was counted at $\times 100$ magnification in a minimum of 10 random fields, and the number of positive profiles $/ \mathrm{mm}^{2}$ calculated. The ABC method of labeling was used on sections in which mast cells were counted because this method more clearly labeled mast cells that were extensively degranulated.

\section{Statistical Analysis}

The data for the numerical density of mast cells were tested by a one-way analysis of variance and individual differences assessed by post hoc Tukey multiple comparisons test using GraphPAD Prism Software, San Diego, California. The data for extent of degranulation was transformed into proportions, subjected to an arcsin transformation and tested for statistical significance by a one-way analysis of variance. A post hoc Dunnett's test was carried out to compare each group with their respective controls using GraphPAD Prism.

All data are presented as the means and standard error of the means (SEM) of $n$ observations, where $n$ refers to the number of animals per group. Multiple sections from single muscle specimens were analyzed in each group. The result was averaged for each rat before calculation of the mean for the whole experimental group.

\section{References}

Adachi H, lida S, Oguchi S, Ohsima H, Suzuki H, Nagasaki K, Kawasaki H, Sugimura T, and Esumi H (1993). Molecular cloning of cDNA encoding an inducible calmodulindependent nitric-oxide synthase from rat liver and its expression in COS1 cells. Eur J Biochem 217:37-43.

Akimitsu T, Gute DC, and Korthius RJ (1995). Ischemic preconditioning attenuates capillary no reflow induced by prolonged ischemia and reperfusion. Am J Physiol 268: H2063-H2067.
Ames A, Wright RI, Kowada M, and Thurston JM (1968). Cerebral ischemia II: The no-reflow phenomenon. Am J Pathol 52:437-453.

Barker JE and Stewart AG (1998). Differing effects of nitric oxide compared with peroxynitrite on mast cell degranulation in vitro. Brit J Pharmacol 123:305p.

Barr ML, Carey JN, Nishanian GP, Roberts RF, Sakamaki Y, Darbinian SH, and Starnes VA (1998). Addition of a mast cell stabilizing compound to organ preservation solutions decreases lung reperfusion injury. J Thorac Cardiovas Surg 115:631-637.

Beckman JS, Beckman TW, Chen J, Marshall PA, and Freeman BA (1990). Apparent hydroxyl radical production by peroxynitrite: Implications for endothelial injury from nitric oxide and superoxide. Proc Natl Acad Sci USA 87:16201624.

Breidahl AF, Hickey MJ, Stewart AG, Hayward PG, and Morrison WA (1996). Effects of low dose intra-arterial monoclonal antibodies to ICAM-1 and CD11/CD18 on ischemia reperfusion injury in the rabbit rectus femoris muscle. $\mathrm{Br} J$ Plast Surg 49:202-209.

Chen LE, Seaber AV, Nasser RM, Stamer JS, and Urbaniak JR (1998). Effects of S-nitroso-N-acetylcysteine on contractile function of reperfused skeletal muscle. Am J Physiol 274:R822-R829.

Chomczynski P and Sacchi N (1987). Single-step method of RNA isolation by acid guanidinium thiocyanate-phenolchloroform extraction. Anal Biochem 162:156-159.

Eiserich JP, Hristova M, Cross CE, Jones AD, Freeman BA, Halliwell B, and van der Vliet A (1998). Formation of nitric oxide derived inflammatory oxidants by myeloperoxidase in neutrophils. Nature 391:393-397.

Forstermann U and Kleinert H (1995). Nitric oxide synthase: Expression and expressional control of the three isoforms. Naunyn-Schmiedebergs Arch Pharmacol 352:351-364.

Galli SJ (1990). New insights into "The riddle of the mast cells": Microenvironmental regulation of mast cell development and phenotypic heterogeneity. Lab Invest 62:5-34.

Galli SJ (1997). The mast cell: A versatile effector cell for a challenging world. Int Arch Allergy Immunol 113:14-22.

Gess B, Schricker K, Pfeifer M, and Kurtz A (1997). Acute hypoxia upregulates NOS gene expression in rats. Am J Physiol 42:R905-R910.

Grace PA (1994). Ischemia-reperfusion injury. Br J Surgery 81:637-647.

Hickey MJ, Hurley JV, and Morrison WA (1996). Temporal and spatial relationship between no-reflow phenomenon and post ischemic necrosis in skeletal muscle. Am J Physiol 271:H1277-H1286.

Huk I, Nanobashvili J, Neumayer C, Punz A, Mueller M, Afkhampour K, Mittlboeck M, Losert U, Polterauer P, Roth E, Patton S, and Malinski T (1997). L-arginine treatment alters the kinetics of nitric oxide and superoxide release and reduces ischemia/reperfusion injury in skeletal muscle. Circulation 96:667-675.

Jolly SR Abrams GD, Romson GD, Bailie MB, and Lurchesidium BR (1982). Effects of Lodoxamide on ischemic reperfused myocardium. J Cardiovascular Pharmacol 4:444448. 
Kanwar S and Kubes $\mathrm{P}$ (1995). Nitric oxide is an antiadhesive molecule for leukocytes. New Horiz 3:93-104.

Keller AM, Clancy RM, Barr ML, Marboe CC, and Canno PJ (1988). Acute reoxygenation injury in the isolated rat heart: Role of resident cardiac mast cells. Circ Res 63:1044-1052.

Kubes P (1993). Polymorphonuclear leukocyte-endothelium interactions: A role for pro-inflammatory and antiinflammatory molecules. Can J Physiol Pharmacol 71:88-97.

Knight KR, Zhang B, Morrison WA, and Stewart AG (1997). Ischemia-reperfusion injury in mouse skeletal muscle is reduced by N-nitro-L-arginine methyl ester and dexamethasone. Eur J Pharmacol 332:273-278.

Knox LK, Stewart AG, Hayward P, and Morrison WA (1994). Nitric oxide synthase inhibitors improve skin flap survival in the rat. Microsurgery 15:708-711.

Lecras TD, Xue C, Rengasamy A, and Johns, RA (1996). Chronic hypoxia upregulates endothelial and inducible NO synthase gene and protein expression in rat lung. Am J Physiol 14:L164-L170.

Lutzelschwab C, Pejler G, Aveskogh M, and Hellman L (1997). Secretory granules proteases in rat mast cells: Cloning of 10 rat mast cell populations. J Exp Med 185:13-29.

Ma XL, Weyrich AS, Lefer DJ, and Lefer A (1993). Diminished basal nitric oxide release after myocardial ischemia and reperfusion promotes neutrophil adherence to coronary endothelium. Circ Res 72:403-412.

Metcalfe DD, Baram D, and Mekori YA (1997). Mast cells. Physiol Rev 77:1033-1079.

Menger MD, Rucker M, and Vollmar B (1997). Capillary dysfunction in striated muscle ischemia reperfusion: On the mechanism of no reflow. Shock 8:2-7.

Moncada S, Palmer RMJ, and Higgs EA (1991). Nitric oxide: Physiology, pathophysiology and pharmacology. Pharmacol Rev 43:109-142.

Noiri E, Peresleni T, Miller F, and Goligorsky MS (1996). In vivo targeting of inducible NO synthase with oligodeoxynucleotides protects rat kidney against ischemia. J Clin Invest 97:2377-2383.

Petrasek PF, Liauw S, Romaschin AD, and Walker PM (1994). Salvage of postischemic skeletal muscle by monoclonal antibody blockade of neutrophil adhesion molecule CD18. J Surg Res 56:5-12.

Phan LH, Hickey MJ, Niazi ZBM, and Stewart AG (1994). The nitric oxide synthase inhibitor nitroiminoethyl-L-ornithine reduces ischemia-reperfusion injury in skeletal muscle. Microsurgery 15:703-707.
Pryor W and Squadrito GL (1995). The chemistry of peroxynitrite: A product from the reaction of nitric oxide with superoxide. Am J Physiol 268:L699-L722.

Pudupakkam S, Harris KA, Jamieson G, Derose G, Scott JA, Carson MW, Schlag MG, Kvietys PR and Potter RF (1998). Ischemic tolerance in skeletal muscle role of nitric oxide. Am J Physiol H94-H99.

Sampson JB, Ye Y, Rosen H, and Beckman JS (1998). Myeloperoxidase and horseradish peroxidase catalyse tyrosine nitration in proteins from nitrite and hydrogen peroxide. Arch Biochem Biophys 15:207-213.

Seekamp A, Mulligan MS, Till GO, and Ward PA (1993). Requirements for neutrophil products and L-arginine in ischemia reperfusion injury. Am J Pathol 142:1217-1226.

Skjeldal S, Torvik A, Grogard B, Nordsletten L, and Lybert T (1993). Histological studies on post-ischemic rat skeletal muscle. Eur Surg Res 25:348-357.

Skjeldal S, Grogaard B, Nordsletten L, Torvik A, Svindland A, and Reikaras O (1994). Does granulocyte depletion protect against ischaemic muscle necrosis? Scand J Clin Lab Invest 54:17-22.

Sobey, CG, Dalipram, R, Dusting GJ, and Woodman OL (1992). Impaired endothelium-dependent relaxation of dog coronary arteries after myocardial ischemia and reperfusion: Prevention by amlodipine, propranolol and allopurinol. $\mathrm{Br} \mathrm{J}$ Pharmacol 105:557-562.

Sternbergh WC, Mackoul RG, and Adelman B (1993). Nitric oxide-mediated, endothelium-dependent vasodilation is selectively attenuated in the post ischemic extremity. Surgery 114:960-967.

Stewart AG, Barker J, and Hickey MJ (In press 1999). Nitric oxide in ischemia-reperfusion injury In: Grace PA and Mathie $R T$, editors. Ischemia-reperfusion injury. Blackwell Scientific, London, pp. 180-195.

Zhang B, Knight KR, Dowsing B, Guida E, Phan LH, Hickey M, Morrison WA, and Stewart AG (1997). Timing of administration of dexamethasone or the nitric oxide inhibitor nitro-Larginine methyl ester, is critical for effective treatment of ischemia reperfusion injury to rat skeletal muscle. Clin Sci 93:167-174. 